\title{
Bay Leaves Improve Glucose and Lipid Profile of People with Type 2 Diabetes
}

\author{
Alam Khan', Goher Zaman', and Richard A. Anderson²,* \\ ${ }^{1}$ Department of Human Nutrition, NWFP Agricultural University, Peshawar, Pakistan \\ ${ }^{2}$ Diet, Genomics and Immunology Laboratory, Beltsville Human Nutrition Research Center, \\ USDA, Beltsville, MD 20705-2350
}

Received 1 July, 2008; Accepted 23 July, 2008

\begin{abstract}
Summary Bay leaves (Laurus nobilis) have been shown to improve insulin function in vitro but the effects on people have not been determined. The objective of this study was to determine if bay leaves may be important in the prevention and/or alleviation of type 2 diabetes. Forty people with type 2 diabetes were divided into 4 groups and given capsules containing 1, 2 or $\mathbf{3} \mathrm{g}$ of ground bay leaves per day for $\mathbf{3 0}$ days or a placebo followed by a 10 day washout period. All three levels of bay leaves reduced serum glucose with significant decreases ranging from 21 to $26 \%$ after 30 d. Total cholesterol decreased, 20 to $24 \%$, after 30 days with larger decreases in low density lipoprotein (LDL) cholesterol of 32 to $40 \%$. High density lipoprotein (HDL) cholesterol increased 29 and $20 \%$ in the groups receiving 1 and $2 \mathrm{~g}$ of bay leaves, respectively. Triglycerides also decreased 34 and $25 \%$ in groups consuming 1 and $2 \mathrm{~g}$ of bay leaves, respectively, after $30 \mathrm{~d}$. There were no significant changes in the placebo group. In summary, this study demonstrates that consumption of bay leaves, 1 to $3 \mathrm{~g} / \mathrm{d}$ for 30 days, decreases risk factors for diabetes and cardiovascular diseases and suggests that bay leaves may be beneficial for people with type 2 diabetes.
\end{abstract}

Key Words: cardiovascular disease, cholesterol, diabetes, triglycerides

\section{Introduction}

Diabetes mellitus is a chronic disorder of glucose metabolism resulting from dysfunction of pancreatic beta cells and insulin resistance. The incidence of cardiovascular diseases is increased two- to four-fold in people with type 2 diabetes [1]. Although the causes of type 2 diabetes and cardiovascular diseases are multifactorial, diet definitely plays a role in the incidence and severity of these diseases. The dietary components beneficial in the prevention and treatment of these diseases have not been clearly defined, but it is postulated that spices may play a role. Spices that have been

\footnotetext{
*To whom correspondence should be addressed.

Tel: +1-301-504-8091 Fax: +1-301-504-9062

E-mail: Richard.anderson@ars.usda.gov
}

reported to be hypoglycemic include fenugreek, garlic, turmeric, cumin, ginger, mustard, curry and coriander [2]. We have also shown that spices such as cinnamon, cloves, bay leaves, and turmeric display insulin-enhancing activity in vitro [3]. Botanical products can improve glucose metabolism and the overall condition of individuals with diabetes not only by hypoglycemic effects but also by improving lipid metabolism, antioxidant status, and capillary function [4].

Based on our in vitro studies, we tested the effects of cinnamon on people with type 2 diabetes [5], the metabolic syndrome [6] and polycystic ovary syndrome and demonstrated that cinnamon or dried aqueous extracts of cinnamon improve glucose and insulin metabolism and circulating blood lipids. Similar properties were expected for bay leaves since cinnamon and bay leaves have similar effects in vitro on insulin action $[3,7]$. Therefore, this study was designed 
to determine whether there is a dose response of bay leaves on clinical variables associated with diabetes and cardiovascular diseases in patients with type 2 diabetes.

\section{Materials and Methods}

This study was conducted in the Department of Human Nutrition, Agricultural University Peshawar, (NWFP) Pakistan. The study was approved by the Ethics Committee and Human Studies Review Board of the University. Selection criteria for the study were that the participating individuals have type 2 diabetes, 40 years old or more, not on insulin therapy and not taking medicines for other health conditions. Subjects were excluded from the study if they had a body mass index greater than $35 \mathrm{~kg} / \mathrm{m}^{2}$, or a history of musculoskeletal, autoimmune or neurologic disease. A total of 40 individuals with type 2 diabetes, 18 men and 22 women, were selected for the study and were divided randomly into four groups and given capsules containing one, two or three $g$ of ground bay leaves or a placebo daily. Subjects were instructed not to change their normal daily routine including medications, foods, and exercise activities.

Bay Leaves (Laurus nobilis) and placebo (corn flour) were ground finely and put into capsules (Noor Drug Agency, Peshawar, Pakistan). Each capsule contained either $500 \mathrm{mg}$ of bay leaves or corn flour. The study was conducted for 40 days, 30 days for bay leaves/placebo and 10 days for washout period. Group 1 consumed $1 \mathrm{~g}$ dose or 2 capsules of bay leaves per day, one after breakfast and the other after dinner. Group 2 consumed $2 \mathrm{~g}$ dose, 2 capsules after breakfast and 2 after dinner. Group 3 consumed $3 \mathrm{~g}$ dose, 3 capsules after breakfast and 3 capsules after dinner. Group 4 consumed 2 capsules of placebo per day, one after breakfast and the other after dinner. The subjects were instructed to take the capsules immediately after meals. Subjects were selected randomly and were not part of a group and were not directly in contact with each other. Compliance was monitored by capsule count and contact with the subjects. Compliance was considered excellent as all capsules were consumed and subjects reported no significant side effects. Subjects continued their normal diets and their diabetic medications throughout the study. The subjects were taking sulfonylurea and metformin drugs. Subjects were not on statin drugs. The medications were not changed during the study.

On days $0,10,20,30$ and 40, $5 \mathrm{ml}$ of fasting blood were collected from each subject. Blood samples were transferred to sterilized centrifuge tubes. The blood samples were centrifuged for $10 \mathrm{~min}$ in a tabletop clinical centrifuge at 4,000 rpm for serum separation. Serum samples were stored in a freezer at $0^{\circ} \mathrm{C}$ for later analyses.

Glucose was determined by the method of Barham et al. [8], triglycerides by the method of Werner et al. [9] and cholesterol was determined by the method of Allain et al. [10] using kits that are commercially available. Low density lipoprotein (LDL) cholesterol was precipitated by adding phosphotungstic acid and magnesium ions to the sample. Centrifugation left only the high density lipoprotein cholesterol (HDL) in the supernatant [11] and, then by the above mentioned cholesterol determination method, HDL was measured. LDL cholesterol was calculated by subtracting collectively the triglycerides/5 and HDL cholesterol from total cholesterol [12].

Two-way ANOVA and randomized complete block design were used for statistical analyses [13]. Values given are means \pm standard deviations. Sample size was selected based upon our previous study for cinnamon and blood glucose [5]. With a difference in means of $2.0 \mathrm{mmol} / \mathrm{L}, \mathrm{SD}$ of 1.3 with four groups of 10 subjects, the power is 0.8 (SigmaStat 3.1, SPSS Inc., Chicago, IL).

\section{Results}

All three levels of bay leaves tested led to decreased fasting serum glucose (Table 1) ranging from 21 to $26 \%$ after 30 days. Values for subjects consuming 1 and $3 \mathrm{~g}$ per day were significant after 10 days while those in the $2 \mathrm{~g}$ group were not significant until 30 days. Fasting glucose of

Table 1. Bay leaves decrease serum glucose in subjects with type 2 diabetes

\begin{tabular}{lcrrrr}
\hline & \multicolumn{3}{c}{ Fasting serum glucose $(\mathrm{mmol} / \mathrm{L})$} \\
\cline { 2 - 6 } $\begin{array}{l}\text { Doses of bay leaves } \\
\text { and placebo (g/day) }\end{array}$ & $\begin{array}{c}\text { Before intake } \\
\text { of bay leaves }\end{array}$ & \multicolumn{2}{c}{ During intake of bay leaves } & \multicolumn{2}{c}{$\begin{array}{c}\text { After intake } \\
\text { of bay leaves }\end{array}$} \\
\cline { 2 - 6 } & Day 0 & Day 10 & Day 20 & Day 30 & Day 40 \\
\hline Bay Leaves 1 & $12.0 \pm 3.6^{\mathrm{a}}$ & $9.0 \pm 2.4^{\mathrm{c}}$ & $10.4 \pm 3.5^{\mathrm{b}}$ & $8.9 \pm 2.6^{\mathrm{c}}$ & $10.2 \pm 2.7^{\mathrm{b}}$ \\
Bay Leaves 2 & $11.3 \pm 3.5^{\mathrm{a}}$ & $11.0 \pm 3.2^{\mathrm{a}}$ & $10.2 \pm 3.4^{\mathrm{a}}$ & $8.8 \pm 2.3^{\mathrm{b}}$ & $10.5 \pm 3.8^{\mathrm{a}}$ \\
Bay Leaves 3 & $16.9 \pm 4.2^{\mathrm{a}}$ & $13.3 \pm 3.9^{\mathrm{b}}$ & $14.0 \pm 2.7^{\mathrm{b}}$ & $13.4 \pm 2.7^{\mathrm{b}}$ & $14.0 \pm 3.1^{\mathrm{b}}$ \\
Placebo 1 & $9.7 \pm 4.1^{\mathrm{a}}$ & $10.3 \pm 5.2^{\mathrm{a}}$ & $9.3 \pm 3.8^{\mathrm{a}}$ & $9.3 \pm 3.9^{\mathrm{a}}$ & $9.4 \pm 3.7^{\mathrm{a}}$ \\
\hline
\end{tabular}

Values are means \pm SD for 10 subjects per treatment.

Means in the same row, with different superscripts, are significantly different at $p<0.05$. Clarification of the different means is further illustrated in bottom of Table 2 . 
Table 2. Bay leaves decrease serum cholesterol in subjects with type 2 diabetes

\begin{tabular}{|c|c|c|c|c|c|}
\hline \multirow{3}{*}{$\begin{array}{l}\text { Doses of bay leaves } \\
\text { and placebo (g/day) }\end{array}$} & \multicolumn{5}{|c|}{ Fasting serum cholesterol $(\mathrm{mmol} / \mathrm{L})$} \\
\hline & \multirow{2}{*}{$\begin{array}{c}\begin{array}{c}\text { Before intake } \\
\text { of bay leaves }\end{array} \\
\text { Day } 0\end{array}$} & \multicolumn{3}{|c|}{ During intake of bay leaves } & \multirow{2}{*}{$\begin{array}{c}\begin{array}{c}\text { After intake } \\
\text { of bay leaves }\end{array} \\
\text { Day } 40\end{array}$} \\
\hline & & Day 10 & Day 20 & Day 30 & \\
\hline Bay Leaves 1 & $6.34 \pm 2.69^{\mathrm{a}}$ & $5.40 \pm 2.74^{\mathrm{abc}}$ & $5.09 \pm 1.63^{\mathrm{bc}}$ & $4.84 \pm 1.55^{\mathrm{c}}$ & $5.97 \pm 1.63^{\mathrm{ab}}$ \\
\hline Bay Leaves 2 & $5.77 \pm 1.16^{\mathrm{a}}$ & $4.58 \pm 0.98^{\mathrm{b}}$ & $4.34 \pm 0.88^{\mathrm{b}}$ & $4.60 \pm 1.03^{\mathrm{b}}$ & $5.59 \pm 1.22^{\mathrm{a}}$ \\
\hline Bay Leaves 3 & $5.84 \pm 1.81^{\mathrm{a}}$ & $5.04 \pm 1.66^{\mathrm{b}}$ & $4.47 \pm 1.58^{\mathrm{b}}$ & $4.63 \pm 1.22^{\mathrm{b}}$ & $4.42 \pm 0.96^{\mathrm{b}}$ \\
\hline Placebo 1 & $5.74 \pm 0.70^{\mathrm{a}}$ & $5.72 \pm 1.03^{\mathrm{a}}$ & $5.66 \pm 0.57^{\mathrm{a}}$ & $5.90 \pm 0.67^{\mathrm{a}}$ & $5.59 \pm 0.72^{\mathrm{a}}$ \\
\hline
\end{tabular}

Conditions defined in Table 1. Means in the same row, with different superscripts, are significantly different at $p<0.05$.

For example, the mean of $6.34 \pm 2.69^{\mathrm{a}}$ is not different from $5.40 \pm 2.74^{\mathrm{abc}}$ and $5.97 \pm 1.63^{\mathrm{ab}}$ (all three contain a superscript (a)) but is different from $5.09 \pm 1.63^{\mathrm{bc}}$ and $4.84 \pm 1.55^{\mathrm{c}}$. Similarly, mean values with common superscripts $\mathrm{b}$ and or $\mathrm{c}$ are also not significantly different.

Table 3. Bay leaves decrease serum LDL cholesterol in subjects with type 2 diabetes

\begin{tabular}{lccccc}
\hline & \multicolumn{3}{c}{ Fasting Serum LDL (mmol/L) } \\
\cline { 2 - 6 } $\begin{array}{l}\text { Doses of bay leaves } \\
\text { and placebo (g/day) }\end{array}$ & $\begin{array}{c}\text { Before intake } \\
\text { of bay leaves }\end{array}$ & Day 10 & During intake of bay leaves & Day 20 & Dafter intake \\
& Day 0 & $2.92 \pm 2.69^{\mathrm{ab}}$ & $2.30 \pm 1.27^{\mathrm{b}}$ & $2.38 \pm 1.68^{\mathrm{b}}$ & $3.52 \pm 1.55^{\mathrm{a}}$ \\
\cline { 2 - 6 } & $3.67 \pm 2.38^{\mathrm{a}}$ & $2.97 \pm 0.88^{\mathrm{b}}$ & $1.97 \pm 0.85^{\mathrm{b}}$ & $2.15 \pm 0.75^{\mathrm{b}}$ & $3.21 \pm 0.98^{\mathrm{a}}$ \\
\hline Bay Leaves 1 & $3.18 \pm 0.85^{\mathrm{a}}$ & $2.61 \pm 1.24^{\mathrm{a}}$ & $1.99 \pm 1.03^{\mathrm{b}}$ & $1.89 \pm 0.72^{\mathrm{b}}$ & $1.99 \pm 0.78^{\mathrm{b}}$ \\
Bay Leaves 2 & $3.10 \pm 1.22^{\mathrm{a}}$ & $3.44 \pm 0.85^{\mathrm{a}}$ & $3.36 \pm 0.59^{\mathrm{a}}$ & $3.57 \pm 0.47^{\mathrm{a}}$ & $3.41 \pm 0.75^{\mathrm{a}}$ \\
Bay Leaves 3 & $3.41 \pm 0.49^{\mathrm{a}}$ & & & & Day 40 \\
Placebo 1 & & &
\end{tabular}

Conditions defined in Table 1.

the subjects who consumed 1 and $3 \mathrm{~g}$ of bay leaves per day also remained significantly lower on day 40 (10 days) after stopping the intake of the capsules) while those of the $2 \mathrm{~g}$ group were not significantly lower after the 10 days washout period. There were no significant changes in the placebo group at any of the time points. It should be noted that the reductions in glucose given in Table 1 and other variables in the following tables are in addition to those due to medication since all subjects continued taking their usual diabetic medicine during the study. There were no significant sex by treatment interactions.

Serum cholesterol also decreased from 21 to $24 \%$ in people with type 2 diabetes consuming 1,2 or $3 \mathrm{~g}$ of bay leaves after 20 days. Values were significant after only 10 days in subjects consuming 2 and $3 \mathrm{~g}$ per day. Values remained significantly lower after the 10 washout period only in the group consuming $3 \mathrm{~g}$ per day (Table 2). There were no significant changes in the placebo group at any of the time points (Table 2).

The largest decrease in cholesterol was in the LDL cholesterol with decreases of 32 to $40 \%$ after 30 days and decreases in all three groups were significant after only 20 days (Table 3). LDL cholesterol of subjects consuming $3 \mathrm{~g}$ of bay leaves per day remained $35 \%$ lower even after the 10 day washout period.

There were also positive effects on HDL cholesterol with increases of 29 and $19 \%$ in subjects taking 1 and $2 \mathrm{~g}$ of bay leaves per day, respectively, after 30 days. Increases were not significant in the group taking $3 \mathrm{~g}$ per day but the baseline of this group of subjects was $0.26 \mathrm{~mol} / \mathrm{L}(10 \mathrm{mg} / \mathrm{dl})$ or more higher than those of either of the groups consuming 1 or $2 \mathrm{~g}$ of bay leaves. There were no significant changes in the placebo group (Table 4).

Bay leaves also reduced serum triglycerides (Table 5). One and $2 \mathrm{~g}$ doses of bay leaves reduced triglycerides 33 and $25 \%$, respectively, after 30 days. Reductions in the subjects consuming $3 \mathrm{~g}$ of bay leaves were variable with significant reductions after 10 days but not after 20 or 30 days but decreases were again significant after the 10 day washout period (Table 5).

\section{Discussion}

This study demonstrates beneficial effects of low levels (1-3 g per day) of bay leaves on glucose, total cholesterol, LDL cholesterol, HDL cholesterol and triglycerides in subjects with type 2 diabetes. It is not clear whether even less than $1 \mathrm{~g}$ of bay leaves per day would also be beneficial. 
Table 4. Bay leaves increase serum HDL cholesterol in subjects with type 2 diabetes

\begin{tabular}{lccccc}
\hline & \multicolumn{4}{c}{ Fasting serum HDL cholesterol (mmol/L) } \\
\cline { 2 - 6 } $\begin{array}{l}\text { Doses of bay leaves } \\
\text { and placebo (g/day) }\end{array}$ & $\begin{array}{c}\text { Before intake } \\
\text { of bay leaves }\end{array}$ & \multicolumn{2}{c}{ During intake of bay leaves } & Day 30 & $\begin{array}{c}\text { After intake } \\
\text { of bay leaves }\end{array}$ \\
\cline { 2 - 6 } & Day 0 & Day 10 & Day 20 & Day 40 \\
\hline Bay Leaves 1 & $1.24 \pm 0.28^{\mathrm{c}}$ & $1.40 \pm 0.28^{\mathrm{bc}}$ & $1.50 \pm 0.26^{\mathrm{ab}}$ & $1.60 \pm 0.31^{\mathrm{a}}$ & $1.47 \pm 0.28^{\mathrm{ab}}$ \\
Bay Leaves 2 & $1.14 \pm 0.36^{\mathrm{b}}$ & $1.29 \pm 0.34^{\mathrm{ab}}$ & $1.37 \pm 0.34^{\mathrm{a}}$ & $1.37 \pm 0.28^{\mathrm{a}}$ & $1.19 \pm 0.34^{\mathrm{b}}$ \\
Bay Leaves 3 & $1.50 \pm 0.41^{\mathrm{a}}$ & $1.42 \pm 0.34^{\mathrm{a}}$ & $1.40 \pm 0.44^{\mathrm{a}}$ & $1.58 \pm 0.41^{\mathrm{a}}$ & $1.55 \pm 0.44^{\mathrm{a}}$ \\
Placebo 1 & $1.27 \pm 0.26^{\mathrm{ab}}$ & $1.22 \pm 0.26^{\mathrm{b}}$ & $1.34 \pm 0.26^{\mathrm{a}}$ & $1.22 \pm 0.21^{\mathrm{b}}$ & $1.16 \pm 0.21^{\mathrm{b}}$ \\
\hline
\end{tabular}

Conditions defined in Table 1.

Table 5. Bay leaves decrease serum triglycerides in subjects with type 2 diabetes

\begin{tabular}{lccccc}
\hline & \multicolumn{4}{c}{ Fasting serum triglycerides (mmol/L) } \\
\cline { 2 - 6 } $\begin{array}{l}\text { Doses of bay leaves } \\
\text { and placebo (g/day) }\end{array}$ & $\begin{array}{c}\text { Before intake } \\
\text { of bay leaves }\end{array}$ & \multicolumn{2}{c}{ During intakes of bay leaves } & \multicolumn{2}{c}{$\begin{array}{c}\text { After intake } \\
\text { of bay leaves }\end{array}$} \\
\cline { 2 - 6 } & Day 0 & Day 10 & Day 20 & Day 30 & Day 40 \\
\hline Bay Leaves 1 & $3.13 \pm 1.48^{\mathrm{a}}$ & $2.38 \pm 2.00^{\mathrm{bc}}$ & $2.81 \pm 1.38^{\mathrm{ab}}$ & $2.09 \pm 1.07^{\mathrm{c}}$ & $2.16 \pm 0.85^{\mathrm{c}}$ \\
Bay Leaves 2 & $3.17 \pm 2.10^{\mathrm{a}}$ & $2.71 \pm 1.66^{\mathrm{ab}}$ & $2.20 \pm 0.96^{\mathrm{b}}$ & $2.39 \pm 1.31^{\mathrm{b}}$ & $2.57 \pm 1.55^{\mathrm{b}}$ \\
Bay Leaves 3 & $2.65 \pm 1.08^{\mathrm{a}}$ & $2.19 \pm 0.90^{\mathrm{bc}}$ & $2.33 \pm 0.79^{\mathrm{abc}}$ & $2.54 \pm 1.28^{\mathrm{ab}}$ & $1.93 \pm 0.87^{\mathrm{c}}$ \\
Placebo 1 & $2.37 \pm 0.91^{\mathrm{a}}$ & $2.30 \pm 0.84^{\mathrm{a}}$ & $2.09 \pm 0.79^{\mathrm{a}}$ & $2.38 \pm 0.88^{\mathrm{a}}$ & $2.18 \pm 0.70^{\mathrm{a}}$ \\
\hline
\end{tabular}

Conditions defined in Table 1.

There was no dose response between 1 and $3 \mathrm{~g}$ daily of bay leaves as responses at all three levels were similar. The maintenance of lower serum glucose and lipid levels, even when the individuals were not consuming bay leaves for 10 days, denotes sustained effects of bay leaves, indicating that bay leaves would not need to be consumed every day. The data are also reinforced by the observation that there were no significant changes in the placebo group. There were also no problems with compliance or problems associated with the consumption of 1 to $3 \mathrm{~g}$ of bay leaves per day.

The randomization of the groups resulted in the group that received $3 \mathrm{~g}$ of bay leaves per day to have significantly higher HDL levels, at the onset of the study, than the groups that received either 1 or $2 \mathrm{~g}$ of bay leaves and is likely the reason why there were no significant effects on the HDL of this group of subjects. A study with larger numbers of subjects is needed to confirm the lack of an improvement in the group that received $3 \mathrm{~g}$ of bay leaves on HDL. There is no reason to assume that the effects of $3 \mathrm{~g}$ of bay leaves on HDL would not also be positive and be similar to the effects of 1 and 2 grams per day.

The active components of bay leaves are under study. Of the 81 compounds representing $98.74 \%$ of total oil of Laurus nobilis, monocyclic monoterpenes such as 1,8-cineole $(58.59 \%)$, alpha-terpinyl acetate $(8.82 \%)$, and terpinene-4-ol $(4.25 \%)$ are the main components. Bicyclic monoterpenes such as alpha- and beta-pinene (3.39-3.25\%) and sabinene
$(3.32 \%)$ are also present. The acyclic monoterpenes, linalool, myrcenol, and sesquiterpenes are found at less than $0.5 \%$. o-Cymene $(1.30 \%)$ and p-cymene $(1.83 \%)$ are also present, and cumin aldehyde, dimethylstyrene, eugenol, methyl eugenol, and carvacrol are minor, aromatic compounds of laurel oil [14]. The active in vitro component of bay leaves is water soluble [3, 7] and is likely not a component of the total oil. Ground cinnamon, has in vivo insulin enhancing activity in experimental animals [15-17] and humans $[5,18]$. However, cinnamon oil does not display in vitro insulin enhancing activity while the water soluble compounds found in cinnamon do display biological activity $[3,7,19]$. Dried aqueous extracts of cinnamon also improve glucose and lipid metabolism in experimental animals [1517, 20, 21]. Similarly, aqueous extracts of cloves display in vitro insulin enhancing activity but clove oil is devoid of activity $[3,7,19]$.

The active component of the bay leaves is likely a polyphenol since more than $80 \%$ of the in vitro insulin potentiating activity was removed by polyvinylpyrrolidone [7], which binds aromatic hydroxyl groups [22].

The mechanisms of the effects of cloves on glucose and lipid concentrations likely involve improvements in insulin sensitivity which would lead to improvements in glucose and blood lipids [1]. Polyphenols found in cinnamon appear to function similarly to the bioactive components in bay leaves; cinnamon compounds have been shown to have 
effects on insulin sensitivity, glucose uptake, antioxidant status, inflammatory response, and glucose emptying [23].

In summary, bay leaves reduced serum glucose, total cholesterol, LDL cholesterol and triglycerides, and increased HDL cholesterol levels in people with type 2 diabetes. Additional studies are needed to confirm these results and also to identify the active components.

\section{Acknowledgements}

The Higher Education Commission / NWFP Agricultural University, Peshawar, Pakistan funded this project, in part. Abstract of study was presented at the Experimental Biology Meeting, Washington, DC, May 2, 2007.

\section{References}

[1] Grundy, S.M.: Metabolic syndrome: connecting and reconciling cardiovascular and diabetes worlds. J. Am. Coll. Cardiol., 47, 1093-1100, 2006.

[2] Srinivasan, K.: Plant foods in the management of diabetes mellitus: spices as beneficial antidiabetic food adjuncts. Int. J. Food Sci. Nutr., 56, 399-414, 2005.

[3] Khan, A., Bryden, N.A., Polansky, M.M., and Anderson, R.A.: Insulin potentiating factor and chromium content of selected foods and spices. Biol. Trace Elem. Res., 24, 183188, 1990.

[4] Bailey, C.J. and Day, C.: Traditional plant medicines as treatments for diabetes [see comments]. Diabetes Care, 12, 553564, 1989.

[5] Khan, A., Safdar, M., Ali Khan, M.M., Khattak, K.N., and Anderson, R.A.: Cinnamon improves glucose and lipids of people with type 2 diabetes. Diabetes Care, 26, 3215-3218, 2003.

[6] Ziegenfuss, T.N., Hofheins, J.E., Mendel, R.W., Landis, J., and Anderson, R.A.: Effects of a water-soluble cinnamon extract on body composition and features of the metabolic syndrome in pre-diabetic men and women. Journal International Society Sport Nutrition, 3, 45-53, 2006.

[7] Broadhurst, C.L., Polansky, M.M., and Anderson, R.A.: Insulin-like biological activity of culinary and medicinal plant aqueous extracts in vitro. J. Agric. Food Chem., 48, 849-852, 2000.

[8] Barham, D. and Trinder, P.: An improved colour reagent for the determination of blood glucose by the oxidase system. Analyst, 97, 142-145, 1972.

[9] Werner, M., Gabrielson, D.G., and Eastman, J.: Ultramicro determination of serum triglycerides by bioluminescent assay. Clin. Chem., 27, 268-271, 1981.

[10] Allain, C.C., Poon, L.S., Chan, C.S., Richmond, W., and Fu,
P.C.: Enzymatic determination of total serum cholesterol. Clin. Chem., 20, 470-475, 1974.

[11] Lopes-Virella, M.F., Stone, P., Ellis, S., and Colwell, J.A.: Cholesterol determination in high-density lipoproteins separated by three different methods. Clin. Chem., 23, 882-884, 1977.

[12] Friedewald, W.T., Levy, R.I., and Fredrickson, D.S.: Estimation of the concentration of low-density lipoprotein cholesterol in plasma, without use of the preparative ultracentrifuge. Clin. Chem., 18, 499-502, 1972.

[13] Freed, R.: MSTAT-C WITH MGRAPH. East Lansing, MI, Michigan State University. Version 2.00. 1997.

[14] Yalcin, H., Anik, M., Sanda, M.A., and Cakir, A.: Gas chromatography/mass spectrometry analysis of Laurus nobilis essential oil composition of northern Cyprus. J. Med. Food, 10, 715-719, 2007.

[15] Verspohl, E.J., Bauer, K., and Neddermann, E.: Antidiabetic effect of Cinnamomum cassia and Cinnamomum zeylanicum in vivo and in vitro. Phytother. Res., 19, 203-206, 2005.

[16] Preuss, H.G., Echard, B., Polansky, M.M., and Anderson, R.: Whole cinnamon and aqueous extracts ameliorate sucroseinduced blood pressure elevations in spontaneously hypertensive rats. J. Am. Coll. Nutr., 25, 144-150, 2006.

[17] Kim, S.H., Hyun, S.H., and Choung, S.Y.: Anti-diabetic effect of cinnamon extract on blood glucose in $\mathrm{db} / \mathrm{db}$ mice. $J$. Ethnopharmacol., 104, 119-123, 2006.

[18] Hlebowicz, J., Darwiche, G., Bjorgell, O., and Almer, L.O.: Effect of cinnamon on postprandial blood glucose, gastric emptying, and satiety in healthy subjects. Am. J. Clin. Nutr., 85, 1552-1556, 2007.

[19] Anderson, R.A., Broadhurst, C.L., Polansky, M.M., Schmidt, W.F., Khan, A., Flanagan, V.P., Schoene, N.W., and Graves, D.J.: Isolation and characterization of polyphenol type-A polymers from cinnamon with insulin-like biological activity. J. Agric. Food Chem., 52, 65-70, 2004.

[20] Qin, B., Nagasaki, M., Ren, M., Bajotto, G., Oshida, Y., and Sato, Y.: Cinnamon extract (traditional herb) potentiates in vivo insulin-regulated glucose utilization via enhancing insulin signaling in rats. Diabetes Res. Clin. Pract., 62, 139148, 2003.

[21] Qin, B., Nagasaki, M., Ren, M., Bajotto, G., Oshida, Y., and Sato, Y.: Cinnamon extract prevents the insulin resistance induced by a high-fructose diet. Horm. Metab. Res., 36, 119$125,2004$.

[22] Wall, M.E., Wani, M.C., Brown, D.M., and Fullas, F.: Effect of tannins on screening of plant extracts for enzyme inhibitory activity and techniques for their removal. Phytomedicine, $\mathbf{3}$, 281-285, 1996.

[23] Anderson, R.A.: Chromium and polyphenols from cinnamon improve insulin sensitivity. Proc. Nutr. Soc., 67, 48-53, 2008. 